\title{
UPAYA MENINGKATKAN PROFESIONALISME GURU IPA SMP DI KECAMATAN SLEMAN MELALUI OPTIMALISASI KEGIATAN LESSON STUDY
}

\author{
Lilik Mardiningsih, Djukri \\ SMPN 3 Tempel Sleman, Universitas Negeri Yogyakarta \\ lilik_m@yahoo.co.id, uny_djukri@yahoo.com
}

\begin{abstract}
Abstrak
Tujuan penelitian untuk meningkatkan profesionalisme guru IPA SMP se Kecamatan Sleman, melalui kegiatan lesson study, sehingga berdampak pada hasil belajar siswa. Jenis penelitian adalah penelitian tindakan dengan menggunakan pendekatan deskriptif kualitatif. Subyek penelitian 32 orang siswa kelas VIII dan 10 orang guru IPA SMP sekecamatan Sleman. Kolaborator adalah guru-guru fisika dari SMP Negeri Kecamatan Sleman. Skenario tindakan meliputi 3 siklus, dengan desain: perencanaan, pelaksanaan tindakan kelas, observasi, refleksi dalam setiap siklus. Metode dan alat pengumpulan data: angket untuk data kuantitatif, observasi dan wawancara untuk data kualitatif, tes prestasi belajar untuk pengukuran hasil. Analisis dan Refleksi dilakukan setiap siklus. Pemaknaan hasil analisis dan kriteria keberhasilan dengan optimalisasi kegiatan lesson study. Hasil penelitian adalah: Kegiatan lesson study dapat meningkatan profesionalisme guru dan berdampak pada peningkatan motivasi belajar siswa. Peningkatan profesionalisme tampak dari peningkatan kompetensi pribadi guru pada siklus 1, ada 15,6\% guru masuk kategori baik dan pada siklus 2 ada 3,1\% berkategori sangat baik, 43,8\% guru berkategori baik. Peningkatan kompetensi profesional guru pada siklus 1, ada 25\% guru berkategori baik, pada siklus 2 ada 9,4\% sangat baik, 37,2\%, baik.
\end{abstract}

Kata kunci: Profesionalisme guru IPA

\section{IMPROVING THE PROFESSIONALISM OF JUNIOR HIGH SCHOOL SCIENCE TEACHERS IN SLEMAN DISTRICT THROUGH LESSON STUDY PROGRAM}

\author{
Lilik Mardiningsih, Djukri \\ SMPN 3 Tempel Sleman, Universitas Negeri Yogyakarta \\ lilik_m@yahoo.co.id, uny_djukri@yahoo.com
}

\begin{abstract}
The aim of Research is to improve the professionalism of a junior high school science teacher in Sleman District, through lesson study, and will impact on student learning outcomes. This type of research is action research using qualitative descriptive approach. The Subjects are 32 eighth grade students and 10 junior high school science teacher in Sleman district. Collaborators are physics teachers on junior high school in Sleman District. The scenario includes 3 action cycle, with designs: planning, implementation class action, observation, and reflection in each cycle. Methods and data collection tools: questionnaires for quantitative data, observation and interviews for qualitative data,and achievement test to measure the results. Analysis and Reflection performed in every cycle. Meaning of the results of analysis and optimization criteria of success with lesson study activities. The results are: Lesson study activity to improve the professionalism of teachers and impacted on increasing student motivation. Increased professionalism shown from increased personal competence of teachers in cycle 1, there was $15.6 \%$ in the category of good teachers and at cycle 2 there is $3.1 \%$ categorized as very good, $43.8 \%$ of teachers in the category of good. Increases professional competence of teachers in cycle 1 , there are $25 \%$ of teachers in the category of good, in cycle 2 there are 9,4\% teachers on very good category, and $37,2 \%$ teachers on good category.
\end{abstract}

Keywords: science teacher professionalism 


\section{Pendahuluan}

Pengembangan keprofesionalan guru akan diikuti oleh peningkatan efektifitas kegiatan belajar mengajar dan secara tidak langsung peningkatan keprofesionalan guru juga akan berdampak pada peningkatan mutu pendidikan secara luas. Guru dipandang profesional apabila memiliki kompetensi-kompetensi dasar yang melandasi pekerjaannya, yaitu kompetensi profesional, kompetensi personal dan kompetensi sosial (Koswara \& Halimah, 2008, p.52). Profesionalisme guru tidak hanya dilihat dari satu kompetensi profesional saja, tetapi juga mencakup kompetensikompetensi yang lainnya. Jenis-jenis kompetensi menurut Peraturan Menteri Pendidikan Nasional Republik Indonesia Nomor 16 Tahun 2007 Tentang Standar Kualifikasi Akademik dan Kompetensi Guru meliputi kompetesi pedagogik, kepribadian, sosial, dan kompetensi profesional.

Kompetensi pedagogik adalah kemampuan seorang guru dalam memahami karakteristik atau kemampuan yang dimiliki oleh murid melalui berbagai cara. Kompetensi kepribadian dibagi ke dalam 5 subkompetensi yaitu: (1) bertindak sesuai norma agama, hukum, sosial dan kebudayaan yang berlaku (2) terampil sebagai pribadi yang jujur dan berakhlak mulia (3) menampilkan diri sebagai pribadi yang mantap (4) menunjukkan etos kerja dan tanggung jawab yang tinggi dan merasa bangga menjadi guru (5) menjunjung tinggi kode etik profesi guru.

Kompetensi sosial menurut Sagala (2009, p.38) meliputi: (1) memahami dan menghargai perbedaan; (2) melaksanakan kerjasama secara harmonis dengan kawan sejawat, kepala sekolah dan pihak-pihak terkait lainnya; (3) membangun kerja tim yang kompak, cerdas, dinamis dan lincah, (4) melaksanakan komunikasi secara efektif; (5) memiliki kemampuan memahami dan menginternalisasikan perubahan lingkungan yang berpengaruh terhadap tugasnya; (6) memiliki kemampuan mendudukkan dirinya dalam system nilai yang berlaku di masyarakat, dan (7) melaksanakan prinsip-prinsip tata kelola yang baik. Kom- petensi profesional merupakan kompetensi guru yang langsung berkaitan dengan tugas utama seorang guru.

Lesson study dapat berperan meningkatkan professional guru. Lesson study adlah suatu proses kolaboratif dimana sekelompok guru mengidentifikasi suatu masalah pembelajaran, merancang suatu skenario pembelajaran (yang meliputi kegiatan mencari buku dan artikel mengenai topik yang akan dibelajarkan), membelajarkan siswa sesuai skenario (salah seorang guru melaksanakan pembelajaran sementara yang lain mengamati), mengevaluasi dan merevisi skenario pembelajaran, membelajarkan lagi skenario pembelajaran yang telah direvisi, mengevaluasi lagi pembelajaran dan membagikan hasilnya dengan guru-guru lain.

Konsep profesional mengacu pada proses internal dan proses eksternal. Proses interal yaitu proses yang diupayakan individu atau kelompok untuk mendapatkan kompetensi yang dibutuhkan melalui pendidikan dan latihan profesi. Proses ini tampak pada adanya organisasi profesi, pengembangan profesional yang berkelanjutan, pengetahuan dan praktik yang terus meningkat, tukar pikiran dengan para ahli, memperlihatkan pribadi yang efisien dan efektif (Martinet, et al, 2001, p.17) Pengertian guru professional adalah guru yang tahu mendalam tentang apa yang diajarkan, mampu mengajarkan secara efektif, efisien dan berkepribadian mantap (Alma, 2012, p.127). Orang yang memiliki kemampuan dan keahlian khusus dalam bidang keguruan sehingga ia mampu melakukan tugas dan fungsinya sebagai guru dengan kemampuan maksimal.

Mengingat tugas dan tanggung jawab guru yang begitu kompleksnya, maka profesi ini memerlukan persyaratan khusus antara lain dikemukakan berikut ini: (1) melibatkan kegiatan intelektual. Ada keterampilan yang berdasarkan konsep dan teori ilmu pengetahuan yang mendalam, (2) memerlukan persiapan profesional yang lama, (3) memerlukan latihan, (4) menentukan baku standarnya sendiri, (5) memiliki organisasi profesi, (6) menjanjikan karier 
hidup dan keanggotaan yang permanen, (7) mementingkan layanan di atas kepentingan individu (Soetjipto \& Kosasi, 2009, p.18). Guru dipandang profesional apabila memiliki kompetensi-kompetensi dasar yang melandasi pekerjaannya, yaitu kompetensi profesional, kompetensi personal dan kompetensi sosial (Koswara \& Halimah, 2008, p.52).

Masalah tentang pendidikan selalu muncul dan diperdebatkan tentang keberadaannya, mulai dari hal-hal yang bersifat fundamental-filsafiah sampai dengan hal-hal yang sifatnya teknis-operasional. Sebagian besar pembicaraan tentang pendidikan tertuju pada bagaimana upaya untuk menemukan cara yang terbaik guna mencapai pendidikan yang bermutu dalam rangka menciptakan sumber daya manusia yang handal, baik dalam bidang akademis, sosio-personal, maupun vokasional.

Lesson study, muncul sebagai salah satu alternatif guna mengatasi masalah praktik pembelajaran yang selama ini dipandang kurang efektif. Seperti dimaklumi, bahwa sudah sejak lama praktik pembelajaran di Indonesia pada umumnya cenderung dilakukan secara konvensional yaitu melalui teknik komunikasi oral. Konsep dan praktik Lesson study pertama kali dikembangkan oleh para guru pendidikan dasar di Jepang, yang dalam bahasa Jepang-nya disebut dengan istilah kenkyuu jugyo. Lesson study merupakan unsur penting dari sistem pendidikan Jepang dan diaktifkan guru SD di Jepang untuk meningkatkan instruksi kelas mereka (Takahashi \& Yoshida, 2004, p.436). Lesson study sangat penting di Jepang karena Lesson study memiliki sejumlah keunggulan, yaitu: memahami ide-ide pendidikan yang didapat dari praktik mengajar, mampu mengubah perspektif guru tentang pengajaran dan belajar, belajar untuk melihat praktek mereka dari perspektif siswa, menikmati dukungan kolaboratif antara rekan-rekan guru. Perry (2009, p.2) mendefinisikan lesson study sebagai suatu proses yang melibatkan guru yang bekerja sama untuk merencanakan, mengobservasi, menganalisis, dan memperbaiki pembelajarannya.
Pembelajaran dalam lesson study sering disebut sebagai "research lesson" atau pembelajaran penelitian. Sukirman (2006, p.2) memandang lesson study sebagai model pembinaan profesi pendidik melalui pengkajian pembelajaran secara kolaboratif dan berkelanjutan berdasarkan prinsip-prinsip kolegalitas dan mutual learning untuk membangun learning community. Dengan demikian lesson study bukan suatu metode pembelajaran atau strategi pembelajaran. Namun demikian, dalam suatu kegiatan lesson study dapat digunakan berbagai metode, strategi, atau pendekatan pembelajaran yang sesuai dengan situasi, kondisi, dan permasalahan yang dihadapi pendidik. Lewis dan Perry (2006, p.90) menyebutkan bahwa: lesson study is a simple idea. If you want to improve instruction, what could be more obvious than collaborating with fellow teachers to plan, observe, and reflect on lessons? While it may be a simple idea, lesson study is a complex process, supported by collaborative goal setting, careful data collection on student learning, and protocols that enable productive discussion of difficult issues.

Berkenaan dengan tahapan-tahapan dalam Lesson Study ini, dijumpai beberapa pendapat. Menurut Chassels C. \& Melville, W (2009, p.736) bahwa lesson study dilakukan melalui empat tahapan dengan menggunakan konsep Plan-Do-CheckAct (PDCA). Sementara itu, Sukirman (2006, p.5) mengemukakan tiga tahapan dalam Lesson Study, yaitu : (1) Perencanaan (Plan); (2) Pelaksanaan (Do) dan (3) Refleksi (See). Sedangkan Bill Cerbin dan Bryan Kopp dari University of Wisconsin mengetengahkan enam tahapan dalam Lesson Study, yaitu: (1) Form a Team: membentuk tim sebanyak 3-6 orang yang terdiri guru yang bersangkutan dan pihak-pihak lain yang kompeten serta memilki kepentingan dengan Lesson Study, (2) Develop Student Learning Goals: anggota tim memdiskusikan apa yang akan dibelajarkan kepada siswa sebagai hasil dari Lesson Study, (3) Plan the Research Lesson: guru-guru mendesain pembelajaran guna mencapai tujuan belajar dan mengantisipasi bagaimana para siswa akan merespons, (4) Gather Evidence 
of Student Learning: salah seorang guru tim melaksanakan pembelajaran, sementara yang lainnya melakukan pengamatan, mengumpulkan bukti-bukti dari pembelajaran siswa, 5) Analyze Evidence of Learning: tim mendiskusikan hasil dan menilai kemajuan dalam pencapaian tujuan belajar siswa, 6) Repeat the Process: kelompok merevisi pembelajaran, mengulang tahapan-tahapan mulai dari tahapan ke-2 sampai dengan tahapan ke-5 sebagaimana dikemukakan di atas, dan tim melakukan sharing atas temuan-temuan yang ada.

\section{Metode Penelitian}

Jenis, Tempat, Waktu dan Subjek Penelitian

Jenis penelitian adalah deskriptif kualitatif, dengan penelitian tindakan berupa lesson study. Data Kuantitatif: data tentang motivasi siswa dikumpulkan melalui angket, data tentang kompetensi kepribadian guru dikumpulkan melalui angket, data tentang kompetensi profesional guru dikumpulkan melalui angket.

Data kualitatif: Data hasil observasi kelas dikumpulkan dengan wawancara dan dokumentasi jurnal harian. Waktu Penelitian ini dilaksanakan pada semester genap Tahun Pelajaran 2008/2009 di SMP Negeri 4 Sleman pada Kelas VIII B. Target/ Subyek penelitian adalah 10 orang guru IPA se Kecamatan Sleman.

Prosedur

\section{Siklus 1}

Siklus 1 meliputi perencanaan, pelaksaanan, observasi, dan refleksi. Perencanaan mencakup: (1) membuat rencana kegiatan lesson study bagi guru IPA untuk pertemuan pertama berupa telaah kurikulum serta menyusun pemetaan SK dan KD yang dilengkapi dengan penilaian; (2) menyusun Rencana Pelaksanaan Pembelajaran (RPP) yang akan dipraktikan di kelas, (3) menyiapakan alat peraga dan praktik serta media yang akan digunakan.

Pelaksanaan mencakup: (1) Guru melaksanakan pembelajaran standar yang meliputi pembukaan, kegiatan inti/pokok dan penutup yang terdiri dari post tes, penegasan konsep penting serta memberi tugas rumah, (2) kolaborator mengamati proses belajar mengajar dengan berpedoman pada lembar observasi guru maupun siswa, (3) Guru hendaknya bersikap sabar, ramah, komunikatif sehingga siswa tidak ada rasa takut terhadap guru dan selama pembelajaran berlangsung guru berkeliling pada kelompok untuk membantu jika ada masalah yang belum dapat terpecahkan, (4) Guru membimbing diskusi kelompok dan dilanjutkan diskusi kelas, sehingga terjadi interaksi antara siswa baik dalam kelompok maupun antar kelompok serta terjadi interaksi antara siswa dengan guru, (5) Guru menyimpulkan/menegaskan hasil diskusi sehingga menjadi catatan/rangkuman bagi siswa, (6) Guru memberi reward pada siswa yang berperan aktif serta memberi motivasi bagi yang kurang aktif, (7) Guru mengadakan evaluasi untuk mengetahui kemajuan siswa dalam belajar, (8) Guru membagikan lembar tugas kepada semua siswa sebagai tugas pra pembelajaran yang akan dikerjakan siswa di luar jam sekolah.

Observasi mencakup: (1) mengadakan observasi di kelas guna evaluasi serta revisi RPP serta alat penilaian yang telah di susun, (2) mengadakan observasi pada kegiatan lesson study untuk penyempurnaan kegiatan lesson study.

Refleksi mencakup: (1) mengadakan refleksi bersama untuk perbaikan pembelajaran di kelas, (2) mengadakan refleksi terhadap pertemuan pertama kegiatan lesson study, guna perbaikan pertemuan berikutnya.

Siklus 2

Pada siklus kedua masih melaksanakan tindakan seperti siklus pertama dengan memperhatikan hasil refleksi dengan tambahan langkah-langkah seperti berikut.

Perencanaan mencakup: (1) peneliti merencanakan mengadakan pelatihan pemilihan metode yang tepat dalam pembelajaran serta menggunakan pendekatan CTL (contextual teaching and learning), (2) Peneliti merencanakan mengadakan pela- 
tihan pemilihan dan penggunaan media pembelajaran dalam kegiatan belajar mengajar, (3) Peneliti bersama anggota lesson study merencanakan pembelajaran dengan pendekatan CTL, (4) Guru model melaksanakan kegiatan pembelajaran sesuai rencana.

Pelaksanaan mencakup: (1) Guru IPA sebagai anggota tim mengikuti pelatihan pemilihan metode yang tepat dalam pembelajaran serta menggunakan pendekatan CTL (contextual teaching and learning), (2) Guru IPA sebagai anggota tim mengikuti pelatihan pemilihan dan penggunaan media pembelajaran dalam kegiatan belajar mengajar, (3) Guru IPA sebagai peserta lesson study membuat pembelajaran dengan pendekatan CTL, (4) Guru model melaksanakan kegiatan pembelajaran sesuai rencana di SMP Negeri 4 Sleman.

Tahap observasi mencakup: (1) Peneliti mengadakan observasi kegiatan lesson study bagi guru IPA se-Kecamatan Sleman, (2) Peneliti mengadakan observasi di kelas untuk mengetahui sejauh mana peningkatan kualitas pembelajaran menggunakan lembar observasi yang telah disusun.

Refleksi mencakup: (1) Peneliti bersama pembimbing mengadakan refleksi untuk perbaikan kegiatan lesson study bagi guru IPA se-Kecamatan Sleman, 2) Peneliti bersama guru model dan anggota lesson study mengadakan refleksi untuk memperbaiki kualitas pembelajaran yang dilakukan oleh guru model.

\section{Siklus 3.}

Pada siklus ini masih melakukan langkah-langkah seperti siklus satu dan dua dengan mempertimbangkan hasil refleksi siklus kedua serta tambahan langkah sebagai berikut.

Perencanaan mencakup: (1) Peneliti merencanakan kegiatan lesson study bagi guru IPA berupa pelatihan penyusunan alat evaluasi dengan mendatangkan nara sumber, 2) Peneliti bersama tim menyusun alat evaluasi, 2) Peneliti bersama tim merencanakan untuk mengadakan evaluasi di akhir siklus menggunakan perangkat evaluasi yang telah disusun.
Pelaksanaan mencakup: (1) Guru IPA mengikuti kegiatan lesson study bagi guru IPA berupa pelatihan penyusunan alat evaluasi dengan mendatangkan nara sumber, (2) Guru IPA bersama tim menysun alat evaluasi, (3) Guru model mengadakan evaluasi di akhir siklus menggunakan perangkat evaluasi yang telah disusun.

Observasi: (1) Peneliti mengadakan observasi terhadap kegiatan lesson study yaitu penyususnan alat evaluasi, (2) Peneliti mengadakan observasi kelas saat pelaksanaan evaluasi di akhir siklus.

Refleksi mencakup: (1) Peneliti bersama pembimbing dan peserta lesson study mengadakan refleksi terhadap pelaksanaan pelatihan penyusunan perangkat evaluasi guna perbaikan pelatihan berikutnya, 2) Peneliti bersama guru model dan semua anggota mengadakan refleksi terhadap pelaksanaan evaluasi di kelas guna perbaikan evaluasi untuk siklus berikutnya.

\section{Teknik Analisis Data}

Analisa data penelitian ini bersifat induktif dengan mengumpulkan buktibukti di lapangan.

\section{Analisis dan Refleksi}

Prosedur analisis yaitu data dianalisis berdasarkan perubahan setiap siklus tentang perilaku guru model dalam pembelajaran, dilihat dari hasil kuesioner siswa mengenai minat mengikuti pelajaran dan hasil evaluasi di akhir siklus.

Pemaknaan hasil analisis dan kriteria keberhasilan yaitu dengan optimalisasi kegiatan lesson study diharapkan dapat meningkakan profesionalisme guru yang berdampak pada peningkatan kualitas pembelajaran. Dengan meningkatnya kualitas pembelajaran sebagai dampaknya diharapkan terjadi peningkatan pemahaman konsep yang ditandai dengan perolehan nilai/ hasil evaluasi. Hasil analisis refleksi siklus pertama, yang berasal dari hasil wawancara peserta lesson study, jurnal, kuesioner dan observasi di kelas digunakan sebagai acuan untuk menentukan tahapan siklus berikutnya yang diharapkan ada peningkatan perilaku berupa kesiapan pembel- 
ajaran sehingga dapat meningkatkan kualitas pembelajaran, peningkatan minat untuk mengikuti pelajaran Fisika yang ditandai dengan meningkatnya nilai hasil evaluasi pemahaman konsep. Jurnal juga sebagai acuan guru untuk memperbaiki cara serta meningkatkan kualitas pembelajaran.

Peningkatan profesionalisme guru diukur berdasarkan data hasil wawancara, angket dari siswa, dan pengamatan. Data dari angket dan pengamatan diolah secara kuantitatif dengan diberi skor penilaian kemudian dibandingkan dengan kriteria yang sudah ditetapkan sebagai berikut (Tabel 1)

Tabel 1. Kriteria Profesionalisme Guru

\begin{tabular}{ccc}
\hline No. & Kriteria & Klasifikasi \\
\hline 1 & $4,2 \leq \overline{\mathrm{X}} \leq 5,0$ & Sangat baik \\
2 & $3,4 \leq \overline{\mathrm{X}}<4,2$ & Baik \\
3 & $2,6 \leq \overline{\mathrm{X}}<3,4$ & Cukup baik \\
4 & $1,8 \leq \overline{\mathrm{X}}<2,6$ & Kurang baik \\
5 & $1,0 \leq \overline{\mathrm{X}}<1,8$ & Sangat tidak baik \\
\hline
\end{tabular}

(Widoyoko, 2011, p.243)

Data hasil wawancara diolah dan dianalisis secara kualitatif deskriptif guna mendeskripsikan upaya meningkatkan profesionalisme guru dan peningkatan profesionalisme itu sendiri.

Berdasarkan wawancara dengan sejumlah guru fisika, indikator kompetensi pribadi yang masih kurang dimiliki oleh para guru fisika pada umumnya yaitu (1) Kemampuan membimbing murid yang berkelainan dan berbakat khusus, (2) Kesediaan mendengar kesulitan siswa dan bersedia diajak berdialog. Dilihat dari banyaknya pilihan jawaban "pernah" pada angket siswa, kompetensi bukan ditunjukkan hanya pernah melakukan, tetapi idealnya adalah sangat sering atau selalu karena aspek kompetensi pribadi melekat dalam diri pribadi guru.

Kompetensi profesional guru fisika menurut para siswa juga masih jauh dari ideal. Sebanyak $65,6 \%$ guru masuk dalam kategori cukup baik dan 34,4\% masuk dalam kategori kurang baik.
Berdasarkan wawancara dengan sejumlah guru, aspek-aspek kompetensi profesional yang dirasakan kurang baik yaitu (1) mengkaji kegiatan-kegiatan pengajaran yang menunjang pencapaian tujuan pendidikan nasional dan (2) guru dapat menyusun alat penilaian. Banyak guru yang sangat bergantung pada LKS dan bukubuku latihan soal sehingga guru tidak terbiasa menyusun instrumen sendiri.

Berdasarkan pengamatan peneliti, banyak aspek yang masih kurang dimiliki para guru fisika, di antaranya: (1) mengenal prinsip-prinsip psikologi pendidikan yang dapat dimanfaatkan dalam proses belajar mengajar, (2) menguasai bahan pengajaran, (3) mengembangan bahan pembelajaran, (4) mengembangkan strategi belajar mengajar, (5) mengembangkan media pengajaran yang sesuai, 6) memanfaatkan sumber belajar, (7) mengelola interaksi belajar mengajar. Hal ini diperkuat dengan bukti yaitu hasil belajar siswa yang masih rendah pada mata pelajaran fisika yaitu kurang dari nilai ketuntasan minimal yang ditetapkan 75. Kondisi ini menjadi alasan kuat diadakannya kegiatan lesson study.

\section{Hasil Penelitian dan Pembahasan}

Skilus 1

Siklus 1 terdiri dari kegiatan perencanaan, pelaksanaan kegiatan, observasi dan refleksi. Perencanaan disusun berdasarkan kondisi awal kompetensi guru yang diketahui dari angket, wawancara dan observasi. Mengingat kegiatan lesson study menekankan pada keterlibatan para guru untuk belajar bersama, maka semua kegiatan dalam siklus 1 dilakukan secara kolaboratif, baik pada saat perencanaan, pelaksanaan, observasi dan refleksi.

\section{Perencanaan}

Kegiatan perencanaan diisi dengan dapat membuat rencana kegiatan lesson study bagi guru IPA. Pada pertemuan pertama, perencanaan diisi dengan telaah kurikulum serta menyusun pemetaan SK dan KD yang dilengkapi dengan penilaian. Kegiatan telaah kurikulum ini diikuti oleh 
10 guru IPA. Telaah kurikulum ini membahas bahan ajar, tujuan pembelajaran, standar kompetensi dan kompetensi dasar, interaksi guru dan siswa dalam strategi pembelajaran di kelas, metode belajar dan media pembelajaran, serta langkah berikutnya dalam kegiatan lesson study.

Hasil telaah menyebutkan bahwa:

(1) Kegiatan pembelajaran tetap harus memenuhi standar pembelajaran yang meliputi pembukaan, kegiatan inti/pokok dan penutup yang terdiri dari post tes, penegasan konsep penting serta memberi tugas rumah.

(2) Pada saat guru model menyampaikan pembelajaran, guru yang lain berperan sebagai kolaborator mengamati proses belajar mengajar dengan berpedoman pada lembar observasi guru maupun siswa.

(3) Guru model selama pembelajaran hendaknya bersikap sabar, ramah, komunikatif sehingga siswa tidak ada rasa takut terhadap guru. Agar lebih komunikatif dan responsif terhadap kesulitan siswa, selama pembelajaran berlangsung guru berkeliling pada kelompok untuk membantu jika ada masalah yang belum terpecahkan.

(4) Metode pembelajaran hendaknya yang dapat melibatan lebih banyak partisipasi siswa, dalam hal ini adalah diskusi. Guru membimbing diskusi kelompok dan dilanjutkan diskusi kelas, sehingga terjadi interaksi antara siswa baik dalam kelompok maupun antar kelompok serta terjadi interaksi antara siswa dengan guru.

(5) Pada akhir diskusi, guru menyimpulkan/menegaskan hasil diskusi sehingga menjadi catatan/rangkuman bagi siswa.

(6) Guru memberi reward pada siswa yang berperan aktif serta memberi motivasi bagi yang kurang aktif.

(7) Guru mengadakan evaluasi untuk mengetahui kemajuan siswa dalam belajar.

(8) Guru membagikan lembar tugas kepada semua siswa sebagai tugas pra pembelajaran yang akan dikerjakan siswa di luar jam sekolah.

Berdasarkan hasil telaah tersebut, setiap peserta lesson study menyusun rancangan pelaksanaan pembelajaran (RPP) yang akan dipraktikan di kelas. Setelah RPP disusun, guru menyiapakan alat peraga dan praktik serta media yang akan digunakan. Guru fisika dari SMP N 2 Sleman diminta untuk menjadi guru model di kelas VIII SMP N 4 Sleman.

\section{Pelaksanaan pembelajaran di kelas}

Pembelajaran di kelas merupakan implementasi dari RPP berdasarkan telaah dalam kegiatan lesson study. Pembelajaran di kelas berlangsung selama 40 menit $\times 2$. Pembelajaran diampu oleh guru model. Kegiatan pembelajaran terdiri dari pendahuluan, inti dan penutup.

\section{Pendahuluan}

Pada kegiatan pendahuluan, guru melakukan apersepsi, yaitu dengan memimpin berdoa, memberi salam, melakukan presensi, menanyakan kesehatan, siapa yang terlambat masuk kelas, siapa yang belajar tadi malam. Apersepsi dimaksudkan untuk mempersiapkan para siswa memasuki materi pelajaran. Selanjutnya, guru memberikan motivasi dengan menyampaikan tujuan pembelajaran dan melakukan tanya jawab tentang pentingnya menguasai ilmu fisika. Pendahuluan ini berlangsung selama 10 menit.

$\underline{\text { Inti }}$

Kegiatan inti berisi tentang materi yang telah disiapkan oleh guru model bersama guru lain pada saat perencanaan. Kegiatan inti terbagi menjadi tiga, yaitu eksplorasi, elaborasi dan konfirmasi. Pada kegiatan eksplorasi, guru melakukan tanya jawab tentang materi. Selanjutnya guru memberikan pengantar sekilas tentang materi fisika kemudian dikaitkan dengan konteks dalam kehidupan sehari-hari siswa.

Kegiatan elaborasi diisi dengan arahan guru agar para siswa aktif berdiskusi agar materi pelajaran mudah dipahami. 
Guru meminta para siswa untuk membentuk kelompok. Diskusi dilakukan dengan bebas, tetapi materi yang didiskusikan adalah tentang standar kompetensi dan kompetensi dasar yang ditetapkan. Selama diskusi dalam kegiatan inti, guru aktif berkeliling mendekati kelompok-kelompok diskusi guna membantu dan memfasilitasi diskusi kelompok agar diskusi berlangsung dinamis.

Kegiatan konfirmasi diisi dengan meminta setiap siswa untuk menyampaikan hasil diskusinya kepada siswa-siswa di depan kelas. Guru mempersilahkan setiap siswa untuk memberikan tanggapan atas hasil diskusi tersebut. Dalam hal ini, guru memantau, membimbing dan mengarahkan proses diskusi.

\section{Penutup}

Kegiatan penutup diisi dengan meminta siswa memberi komentar terhadap kegiatan belajar mengajar yang dialami. Siswa juga diminta menyimpulkan materi yang dipelajari. Dalam hal ini, guru membantu agar para siswa menemukan kesimpulan sesuai pemahaman siswa. Selanjutnya, guru menegaskan konsep-konsep penting serta memberi tugas rumah.

Berdasarkan observasi selama berlangsungnya pembelajaran, guru-guru kolaborator mengamati proses belajar mengajar dengan berpedoman pada lembar observasi guru maupun siswa. Guru tampak berusaha bersikap sabar, ramah, komunikatif sehingga siswa tidak ada rasa takut terhadap guru. Komunikasi antara guru dan siswa cukup baik, selama pembelajaran berlangsung guru berkeliling pada kelompok untuk membantu jika ada masalah yang belum dapat terpecahkan.

Guru aktif membimbing diskusi kelompok dan dilanjutkan diskusi kelas, sehingga terjadi interaksi antara siswa baik dalam kelompok maupun antarkelompok serta terjadi interaksi antara siswa dengan guru. Guru berperan dalam menyimpulkan/menegaskan hasil diskusi sehingga menjadi catatan/rangkuman bagi siswa.

Pemberian motivasi selama berjalannya pembelajaran juga berlangsung baik.
Guru memberi reward pada siswa yang berperan aktif serta memberi motivasi bagi yang kurang aktif. Pada akhir pembelajaran, guru mengadakan evaluasi secara acak dan lisan untuk mengetahui kemajuan siswa dalam belajar. Guru bertanya dan meminta siswa untuk menjawab. Guna menyiapkan siswa agar lebih siap mengikuti pembelajaran pada pertemuan selanjutnya, guru membagikan lembar tugas kepada semua siswa sebagai tugas pra pembelajaran yang akan dikerjakan siswa di luar jam sekolah.

Kemampuan guru dalam memotivasi siswa-siswa diukur berdasarkan motivasi yang dirasakan oleh para siswa seperti hasil angket yang disajikan pada Tabel 2.

Tabel 2. Motivasi Siswa Mengikuti Pembelajaran Fisika Siklus 1

\begin{tabular}{ccc}
\hline Interval & $\mathrm{f}$ (frekuensi) & Presentase \\
\hline $4,2 \leq \overline{\mathrm{X}} \leq 5,0$ & 0 & $0,00 \%$ \\
$3,4 \leq \overline{\mathrm{X}}<4,2$ & 12 & $37,50 \%$ \\
$2,6 \leq \overline{\mathrm{X}}<3,4$ & 10 & $31,25 \%$ \\
$1,8 \leq \overline{\mathrm{X}}<2,6$ & 4 & $12,50 \%$ \\
$1,0 \leq \overline{\mathrm{X}}<1,8$ & 6 & $18,75 \%$ \\
& 32 & $100 \%$ \\
\hline
\end{tabular}

Sumber: data pengolahan angket Siswa.

Sebanyak $37,50 \%$ siswa merasa memiliki motivasi tinggi, 31,25\% memiliki motivasi cukup tinggi, $12,50 \%$ siswa kurang termotivasi, dan $18,75 \%$ siswa tidak termotivasi. Hal ini memperlihatkan masih banyak siswa yang harus ditingkatkan motivasinya untuk mengikuti pelajaran fisika.

Berdasarkan observasi yang dilakukan oleh kolaborator, kemampuan guru sudah cukup baik. Hasil observasi memperlihatkan pada tahap persiapan, guru sudah memberikan motivasi dan membangkitkan minat belajar siswa. guru juga sudah melakukan apersepsi. Pada kegiatan inti, guru sudah menunjukkan pendekatan kontekstual, mendorong tumbuhnya aktivitas siswa, guru menerangkan secara lisan/tertulis, adanya peguatan/penghargaan pada siswa, dan telah adanya penyajian materi secara sistematis. Demikian pula 
pada saat penutupan pembelajaran, guru membantu siswa untuk menemukan kesimpulan.

Setelah pembelajaran ditutup, peneliti dibantu para guru kolaborator membagikan angket untuk mengetahui penilaian dari siswa tentang kompetensi yang dimiliki guru model selama berlangsungnya pembelajaran. Hasil angket tentang kompetensi pribadi guru disajikan pada Tabel 3 .

Tabel 3. Kompetensi Pribadi pada Siklus 1

\begin{tabular}{ccc}
\hline Interval & $\mathrm{f}$ (frek.) & Persentase \\
\hline $4,2 \leq \overline{\mathrm{X}} \leq 5,0$ & 0 & $0 \%$ \\
$3,4 \leq \overline{\mathrm{X}}<4,2$ & 5 & $15,6 \%$ \\
$2,6 \leq \overline{\mathrm{X}}<3,4$ & 22 & $68,7 \%$ \\
$1,8 \leq \overline{\mathrm{X}}<2,6$ & 5 & $15,6 \%$ \\
$1,0 \leq \overline{\mathrm{X}}<1,8$ & 0 & $0 \%$ \\
& 32 & $100 \%$ \\
\hline
\end{tabular}

Sumber: data pengolahan angket Siswa.

Menurut para siswa, kompetensi pribadi para guru memperlihatkan peningkatan. Sebanyak $15,6 \%$ guru masuk dalam kategori baik, 68,7\% guru masuk dalam kategori cukup baik , dan 15,6\% guru masuk dalam kategori kurang baik. Artinya, meskipun ada peningkatan, kompetensi pribadi guru belum sesuai dengan harapan siswasiswanya.

Berdasarkan wawancara dengan sejumlah guru peserta lesson study, peningkatan kompetensi tersebut terutama dalam aspek kesediaan mendengar kesulitan siswa dan bersedia diajak berdialog, kemampuan membimbing murid yang berkelainan dan berbakat khusus, dan membimbing siswa yang mengalami kesulitan belajar. Hal ini memperlihatkan bahwa kegiatan lesson study pada siklus 1 berhasil meningkatkan kompetensi pribadi guru.

Peningkatan kompetensi profesional guru yang dirasakan oleh para siswa selama pembelajaran siklus 1 disajikan pada Tabel 4.

Kompetensi profesional guru menurut pendapat para siswa mengalami peningkatan. Sebanyak 25\% guru masuk kategori baik, 53,1\% masuk kategori cukup baik, dan 21,8\% masuk kategori kurang baik. Berdasarkan wawancara dengan sejumlah guru, aspek kompetensi profesional yang mengalami peningkatan yaitu pada aspek menerapkan prinsip-prinsip belajar dalam kegiatan belajar mengajar, bersedia menerima masukan dari teman sejawatnya, mengenal prinsip-prinsip psikologi pendidikan yang dapat dimanfaatkan dalam proses belajar mengajar, dan berinteraksi dengan sejawat untuk meningkatkan kemampuan profesional. Meskipun ada peningkatan, persentase guru yang dipandang hanya cukup masih banyak yaitu ada $53,1 \%$. Artinya, masih banyak guru yang belum memenuhi harapan siswa.

Tabel 4. Kompetensi Profesional pada Siklus 1

\begin{tabular}{ccc}
\hline Interval & $\mathrm{f}$ (frek.) & Persentase \\
\hline $4,2 \leq \bar{X} \leq 5,0$ & 0 & $0 \%$ \\
$3,4 \leq \overline{\mathrm{X}}<4,2$ & 8 & $25 \%$ \\
$2,6 \leq \overline{\mathrm{X}}<3,4$ & 17 & $53,1 \%$ \\
$1,8 \leq \overline{\mathrm{X}}<2,6$ & 7 & $21,8 \%$ \\
$1,0 \leq \overline{\mathrm{X}}<1,8$ & 0 & $0 \%$ \\
& 32 & $100 \%$ \\
\hline
\end{tabular}

Sumber: data pengolahan angket Siswa.

Refleksi

Hasil anget siswa, hasil postes, hasil observasi kolaborator dan hasil wawancara memperlihatkan adanya peningkatan kompetensi profesional guru, hanya saja peningkatan yang dicapai belum maksimal. Persentase guru yang belum memiliki kompetensi tinggi atau baik masih cukup besar yaitu ada 50\%. Para guru diajak untuk merefleksikan kembali kegiatan lesson study mulai dari perencanaan, dan pelaksanaan pembelajaran. Setiap guru diminta untuk memberikan kesimpulan akhir. Berdasarkan hasil refleksi disimpulkan bahwa lesson study perlu dilanjutkan dengan mengadakan pelatihan pembelajaran dengan pendekatan Contextual Teaching and Learning (CTL).

Siklus ke 2

Pengamatan selama kegiatan lesson study bagi guru IPA se-Kecamatan Sleman 
melihat aspek kompetensi profesional guru. Hasil pengamatan memperlihatkan bahwa guru-guru menunjukkan minat yang baik untuk menguasai pendekatan CTL. Pemahaman guru-guru IPA tentang CTL cukup beragam sehingga kegiatan lesson study juga menjadi forum untuk saling mengkonfirmasi pemahaman para guru tentang aspek-aspek dalam CTL.

Peneliti mengadakan observasi di kelas untuk mengetahui sejauh mana peningkatan kualitas pembelajaran menggunakan lembar observasi yang telah disusun. Observasi dibantu oleh guru kolaborator. Hasil observasi memperlihatkan adanya peningkatan kompetensi guru. Peningkatan ini tampak dari kemampuan guru mengelola kelas, mengkaitkan pembelajaran dengan konteks, menumbuhkan motivasi siswa dan membantu siswa-siswa yang mengalami kesulitan belajar. Hasil analisis siswa mengikuti pembelajaran fisika disajikan kedalam Tabel 5.

Tabel 5. Motivasi Siswa Mengikuti Pembelajaran Fisika Siklus 1

\begin{tabular}{ccc}
\hline Interval & $\mathrm{f}$ (frek.) & Persentase \\
\hline $4,2 \leq \overline{\mathrm{X}} \leq 5,0$ & 3 & $9,3 \%$ \\
$3,4 \leq \overline{\mathrm{X}}<4,2$ & 7 & $21,87 \%$ \\
$2,6 \leq \overline{\mathrm{X}}<3,4$ & 16 & $50,00 \%$ \\
$1,8 \leq \overline{\mathrm{X}}<2,6$ & 6 & $18,75 \%$ \\
$1,0 \leq \overline{\mathrm{X}}<1,8$ & - & $0 \%$ \\
& 32 & $100 \%$ \\
\hline
\end{tabular}

Sumber: data pengolahan angket Siswa.

Motivasi belajar siswa memperlihatkan adanya peningkatan. Siswa dengan motivasi cukup ada 16 (50\%), siswa dengan motivasi tinggi ada $7(21,87 \%)$, dan siswa sangat tinggi motivasinya ada $3(9,3 \%)$. Peningkatan motivasi siswa merupakan dampak dari adanya peningkatan kompetensi guru setelah mengikuti lesson study.

Pada akhir pembelajaran, siswasiswa diminta untuk mengisi angket penilaian untuk mengetahui kompetensi guru selama pembelajaran pada siklus 2. Jawaban siswa dideskripsikan pada Tabel 6 .

Tabel 6 memperlihatkan para siswa menilai kompetensi pribadi para guru mengalami peningkatan. Sebanyak 3,1\% guru memiliki kompetensi pribadi sangat baik, 43,8\% guru masuk dalam kategori baik, 43,8\% guru masuk dalam kategori cukup baik, dan 9,4\% guru masuk dalam kategori kurang baik. Artinya, kompetensi pribadi guru yang belum sesuai dengan harapan siswa-siswanya masih ada 9,4\%. Peningkatan komptensi juga tampak pada kompetensi profesional seperti tampak pada Tabel 7.

Tabel 6. Kompetensi Pribadi Guru pada Siklus 2

\begin{tabular}{ccc}
\hline Interval & $\mathrm{f}$ (frek.) & Persentase \\
\hline $4,2 \leq \overline{\mathrm{X}} \leq 5,0$ & 1 & $3,1 \%$ \\
$3,4 \leq \overline{\mathrm{X}}<4,2$ & 14 & $43,8 \%$ \\
$2,6 \leq \overline{\mathrm{X}}<3,4$ & 14 & $43,8 \%$ \\
$1,8 \leq \overline{\mathrm{X}}<2,6$ & 3 & $9,4 \%$ \\
$1,0 \leq \overline{\mathrm{X}}<1,8$ & 0 & $0,00 \%$ \\
\multicolumn{2}{c}{ Sumber: data pengolahan angket Siswa. }
\end{tabular}

Tabel 7. Kompetensi Profesional Guru pada Siklus 2

\begin{tabular}{ccc}
\hline Interval & $\mathrm{f}$ (frek.) & Persentase \\
\hline $4,2 \leq \overline{\mathrm{X}} \leq 5,0$ & 3 & $9,4 \%$ \\
$3,4 \leq \bar{X}<4,2$ & 12 & $37,2 \%$ \\
$2,6 \leq \bar{X}<3,4$ & 15 & $46,9 \%$ \\
$1,8 \leq \bar{X}<2,6$ & 2 & $6,3 \%$ \\
$1,0 \leq \bar{X}<1,8$ & 0 & $0,00 \%$ \\
& 32 & $100 \%$ \\
\hline
\end{tabular}

Sumber: data pengolahan angket Siswa.

Kompetensi profesional guru mengalami peningkatan. Sebanyak 9,4\% guru sangat baik, 37,2\% guru masuk kategori baik, 46,9\% masuk kategori cukup baik, dan 6,3\% masuk kategori kurang baik. Dari wawancara dengan sejumlah guru, aspek kompetensi profesional yang mengalami peningkatan yaitu pada aspek menerapkan prinsip-prinsip belajar dalam kegiatan belajar mengajar, bersedia menerima masukan dari teman-teman sejawatnya, mengenal prinsip-prinsip psikologi pendidikan yang dapat dimanfaatkan dalam proses belajar mengajar, dan berinteraksi 
dengan teman sejawat untuk meningkatkan kemampuan profesional. Meskipun ada peningkatan, persentase guru yang dipandang masih kurang ada 6,3\%. Artinya, masih ada guru yang belum memenuhi harapan siswa.

\section{Refleksi}

Hasil tindakan pada siklus 2 telah memperlihatkan adanya peningkatan kompetensi pribadi dan kompetensi profesional guru. Meskipun persentase guru yang dipandang masih kurang memiliki kompetensi masih cukup besar, yaitu ada $40 \%$ dengan kompetensi pribadi masuk dalam kategori kurang baik dan ada $28,1 \%$ guru dengan kompetensi profesional kurang baik, tetapi secara nyata ada peningkatan profesionalisme guru.

Berdasarkan masukan peserta lesson study, diputuskan untuk melanjutkan pada siklus 3 dengan pemberian tindakan brupa latihan penyusunan alat evaluasi. Pertimbangannya aspek-aspek apa saja dari kompetensi guru fisika sudah dipahami dan ada kesediaan dari para peserta untuk mengimplementasikan hasil lesson study seperti dihasilkan dari siklus 2 .

Siklus ke 3

Siklus 3 merupakan kelanjutan dari siklus 2. Siklus 3 terdiri dari kegiatan perencanaan, pelaksanaan pembelajaran, observasi, dan refleksi.

\section{Perencanaan}

Kegiatan perencanaan diisi dengan menyusun sejumlah kegiatan guna mengadakan pelatihan berupa pelatihan penyusunan alat evaluasi dengan mendatangkan nara sumber. Peneliti bersama tim menyusun alat evaluasi dan merencanakan untuk mengadakan evaluasi di akhir siklus menggunakan perangkat evaluasi yang telah disusun. Siklus ini secara spesifik bertujuan untuk meningkatkan profesionalisme guru dalam melakukan evaluasi pembelajaran.

\section{Pelaksanaan}

Pelaksanaan tindakan lesson study dilakukan berupa pelatihan penyusunan alat evaluasi dengan mendatangkan nara sumber. Pada kesempatan ini, narasumber yang memberikan materi adalah pengawas yang telah mengikuti pelatihan evaluasi. Jadi pelatihan dalam lesson study ini bersifat desiminasi saja. Kegiatan pelatihan ini diikuti oleh 10 orang guru fisika. Guruguru peserta langsung mempraktikan cara menyusun alat evaluasi kemudian didiskusikan kelebihan dan kekurangannya. Selanjutnya, alat evaluasi yang berhasil disusun digunakan oleh para guru untuk melakukan evaluasi pembelajaran pada siklus akhir.

\section{Observasi}

Observasi terhadap kegiatan lesson study dilaksanakan selama kegiatan lesson study yaitu penyusunan alat evaluasi. Selama pelatihan, guru-guru memperhatikan masukan dari pemateri. Guru-guru aktif berpartisipasi dengan mengajukan pertanyaan atau tanggapan tentang berbagai model evaluasi pembelajaran yang dibahas dalam lesson study.

Pada akhir pelatihan, guru-guru diberi angket berisi sejumlah pertanyaan yang dijawab sendiri oleh para guru. Pertanyaan yang diajukan adalah seputar pemahaman tentang alat evaluasi pembelajaran. Jawaban dari para guru memperlihatkan peningkatan pemahaman para guru tentang evaluasi pembelajaran.

Refleksi.

Pada akhir latihan, setelah para guru menyatakan memahami penyusunan alat evaluasi, bersama pembimbing dan peserta lesson study mengadakan refleksi terhadap pelaksanaan pelatihan penyusunan perangkat evaluasi. Semua peserta sepakat bahwa alat evaluasi yang disusun bersama dalam lesson study dapat diimplementasikan guna meningkatkan kualitas pembelajaran.

\section{Pembahasan}

Berdasarkan hasil penelitian dari 3 siklus, tampak bahwa kegiatan lesson study dapat meningkatan kompetensi para guru fisika. Pembahasan berikut ini memperli- 
hatkan bagaimana peningkatan bertahap terjadi dan sejauhmana dapat dibuktikan.

\section{Peningkatan Kompetensi Pribadi}

Peningkatan kompetensi pribadi dapat diketahui dengan cara membandingkan antara kompetensi sebelum lesson study dengan kompetensi setelah lesson study berakhir. Perbandingan prasiklus dan antar siklus tampak pada Tabel 8.

Tabel 8. Perbandingan kompetensi pribadi Antar Siklus

\begin{tabular}{cccccc}
\hline No & Kriteria & Klasifikasi & Prasiklus & $\begin{array}{c}\text { Siklus } \\
1\end{array}$ & $\begin{array}{c}\text { Siklus } \\
2\end{array}$ \\
\hline 1 & $4,2 \leq \overline{\mathrm{X}} \leq 5,0$ & $\begin{array}{c}\text { Sangat } \\
\text { baik }\end{array}$ & $0 \%$ & $0 \%$ & $3,1 \%$ \\
2 & $3,4 \leq \overline{\mathrm{X}}<4,2$ & baik & $6,3 \%$ & $15,6 \%$ & $43,8 \%$ \\
3 & $2,6 \leq \overline{\mathrm{X}}<3,4$ & $\begin{array}{c}\text { Cukup } \\
\text { baik }\end{array}$ & $65,6 \%$ & $68,7 \%$ & $43,8 \%$ \\
4 & $1,8 \leq \overline{\mathrm{X}}<2,6$ & $\begin{array}{c}\text { Kurang } \\
\text { baik }\end{array}$ & $28,1 \%$ & $15,6 \%$ & $9,4 \%$ \\
5 & $1,0 \leq \overline{\mathrm{X}}<1,8$ & $\begin{array}{c}\text { Sangat } \\
\text { tidak baik }\end{array}$ & $0 \%$ & $0 \%$ & $0,00 \%$ \\
\hline
\end{tabular}

Tabel 8 memperlihatkan kompetensi pribadi bergerak ke arah yang semakin baik. Kondisi awal atau prasiklus tidak ada guru yang masuk dalam kategori baik. Pada siklus 1 ada 15,6\% guru yang masuk kategori baik, 68,7\% cukp baik, dan ada 15,6\% kurang baik. Pada siklus 2 ada 3,1\% masuk kategori sangat baik, ada 43,8\% guru masuk kategori baik dan ada 9,4\% masuk kategori kurang baik.

\section{Peningkatan Kompetensi Profesional}

Peningkatan kompetensi profesional dapat diketahui dengan cara membandingkan antara kompetensi sebelum lesson study dengan kompetensi setelah lesson study berakhir. Perbandingan prasiklus dan antar siklus tampak pada Tabel 9.

Tabel 9 memperlihatkan kompetensi profesional bergerak ke arah yang semakin baik. Kondisi awal atau prasiklus tidak ada guru yang masuk dalam kategori baik. Pada siklus 1, ada 25\% guru masuk kategori baik, ada 53,1\% masuk kategori cukup, ada $21,8 \%$ kurang baik. Pada siklus 2 ada 9,4\% masuk kategori sangat baik, ada
$37,2 \%$ masuk kategori baik, 46,9 masuk kategori cukup, ada 6,3\% guru masuk kategori kurang baik.

Tabel 9. Perbandingan Kompetensi Profesional Antarsiklus

\begin{tabular}{|c|c|c|c|c|c|}
\hline No & Kriteria & Klasifikasi & $\begin{array}{l}\text { Prasiklu } \\
\text { s }\end{array}$ & $\begin{array}{c}\text { Siklus } \\
1\end{array}$ & $\begin{array}{c}\text { Siklus } \\
2\end{array}$ \\
\hline 1 & $4,2 \leq \bar{X} \leq 5,0$ & Sangat baik & $0 \%$ & $0 \%$ & $9,4 \%$ \\
\hline 2 & $3,4 \leq \bar{X}<4,2$ & baik & $0 \%$ & $25 \%$ & $37,2 \%$ \\
\hline 3 & $2,6 \leq \bar{X}<3,4$ & Cukup baik & $65,6 \%$ & $53,1 \%$ & $46,9 \%$ \\
\hline 4 & $1,8 \leq \overline{\mathrm{X}}<2,6$ & Kurang baik & $34,4 \%$ & $21,8 \%$ & $6,3 \%$ \\
\hline \multirow[t]{2}{*}{5} & $1,0 \leq \bar{X}_{<1,8}$ & $\begin{array}{c}\text { Sangat tidak } \\
\text { baik }\end{array}$ & $0 \%$ & $0 \%$ & $0,00 \%$ \\
\hline & & & $100 \%$ & $100 \%$ & $100 \%$ \\
\hline
\end{tabular}

Aspek komptensi profesional yang mengalami peningkatan terutama yaitu: (a) Mengenal prinsip-prinsip psikologi pendidikan yang dapat dimanfaatkan dalam proses belajar mengajar; (b) menerapkan prinsip-prinsip belajar dalam kegiatan belajar mengajar; (c) menguasai bahan pengajaran kurikulum pendidikan dasar dan menengah: (d) guru memilih dan mengembangkan media pengajaran yang sesuai; (e) menciptakan iklim belajar mengajar yang tepat: (f) Guru dapat menilai proses belajar mengajar yang telah dilaksanakan

Keberadaan lesson study memberikan manfaat bagi peningkatan kompetensi guru IPA. Peningkatan terjadi karena di dalam lesson study guru dapat membangun sebuah pengetahuan pedagogis sehingga seorang guru dapat menimba pengetahuan dari guru lainnya, guru memperoleh pemahaman yang lebih baik tentang bagaimana siswa belajar dan guru mengajar, guru dapat memperoleh umpan balik dari anggota/komunitas lainnya dan guru dapat mendokumentasikan kemajuan kerjanya.

Penelitian ini memiliki keterbatasan pada sumber data dan alat ukur untuk mengetahui kompetensi pribadi. siswa-siswa tidak banyak yang tahu kegiatan guru di luar sekolah sehingga dalam memberikan penilaian tentang kompetensi guru dapat saja kurang valid. Data dari wawancara dan observasi kurang kuat sehingga perlu adanya proses memperpanjang penelitian. 


\section{Simpulan dan Saran}

Simpulan

Berdasarkan hasil penelitian dan pembahasan pada bab sebelumnya, dapat diambil simpulan sebagai berikut.

Peratam, upaya peningkatan profesionalisme guru melalui lesson study dilakukan sebanyak tiga siklus. Pada siklus 1, lesson study diisi dengan kegiatan berupa telaah kurikulum, penyusunan RPP dan pelaksanaan pembelajaran di dalam kelas. Pada siklus 2, lesson study diisi dengan latihan pembelajaran dengan pendekatan CTL dilanjutkan dengan praktik mengajar di dalam kelas. Pada siklus 3, lesson study diisi dengan pelatihan penyusunan alat evaluasi pembelajaran.

Kedua, Kegiatan lesson study dapat meningkatan profesionalisme guru dan berdampak pada peningkatan motivasi belajar siswa. Peningkatan profesionalisme tampak dari peningkatan kompetensi pribadi guru dan peningkatan kompetensi profesional guru. Kompetensi pribadi pada siklus 1 , ada $15,6 \%$ guru yang masuk kategori baik, masuk kategori cukup ada $68,7 \%$ dan kurang ada 15,6\%. Pada siklus 2 ada $3,1 \%$ masuk kategori sangat baik, 43,8\% guru masuk kategori baik, 43,8\% masuk cukup, dan ada 9,4\% kurang baik. Kompetensi profesional pada siklus 1, ada $25 \%$ guru yang masuk kategori baik, 53,1\% masuk kategori cukup dan ada 21,8\% masuk kategori kurang baik ada 21,8\%. Pada siklus 2 ada $9,4 \%$ sudah sangat baik, masuk baik ada $37,2 \%$, cukup ada $46,9 \%$ dan kurang baik ada $63 \%$.

Saran/Implikasi

Berdasarkan simpulan yang telah disampaikan, maka dapat ditarik kesimpulan sebagai berikut.

Pertama, Lesson study sebaiknya terus digunakan untuk meningkatkan kompetensi guru sehingga kualitas pembelajaran terus berkembang. Kedua, Para guru sebaiknya melakukan evaluasi diri agar mengetahui aspek-aspek yang termasuk lemah dalam dirinya sehingga dapat menjadi bahan untuk meningkatkan kompetensinya.

\section{Daftar Pustaka}

Alma, B., (2012). Guru profesional, menguasai metode dan keterampilan mengajar. Jakarta: Alfabeta

Koswara, D. \& Halimah. (2008). Seluk beluk profesi guru. Bandung: Pribumi Mekar

Lewis, C. \& Perry, R. (2006). What is successful adaptation of lesson study in the US? Journal of Educational Change, 10, 365-391

Martinet, M.A., Raymond, D., \& Gauthier, C. (2001). Teacher training: Orientations professional competencies. Québec: Ministère de l'Éducation.

Mendiknas, Peraturan Menteri Pendidikan Nasional Nomor 16 Tahun 2007 Tentang Standar Kualifikasi Akademik dan Kompetensi Guru

Republik Indonesia, Peraturan pemerintah nomor 14 tahun 2005 Tentang Guru dan Dosen.

Republik Indonesia, Peraturan pemerintah nomor 19 tahun 2005 tentang standar pendidikan nasional.

Soetjipto \& Kosasi, R. (2009). Profesi keguruan, Jakarta: Rineka Cipta dan Depdiknas.

Suciati. (2007). Belajar dan pembelajaran, Jakarta: Universitas Terbuka.

Sukirman. (2006). Peningkatan profesional guru melalui lesson study. Makalah Disampaikan pada Kegiatan Pelatihan 2 Hari untuk Fasilitator dan Tim TPK SISTTEMS Bantul Emergency Program, 11 - 12 Agustus 2006.

Takahashi A. \& Yoshida, M. (2004). Ideas for Establishing Lesson-Study Communities, The National Council of Teachers of Mathematics, Inc. www.nctm.org. diakses tanggal 12 Juni 2010

Usman, M.U. (2004). Menjadi guru profesional. Bandung: Rosdakarya

Widoyoko, E. (2011), Pengantar evaluasi program pembelajaran, Yogyakarta: Pustaka Pelajar. 